\title{
Systematic review on knowledge and skills level among nurses following cardiopulmonary resuscitation (cpr) training
}

\author{
S Ahmed \\ Universiti Putra Malaysia \\ I Ismail ( $\square$ iskasymar@upm.edu.my) \\ Universiti Putra Malaysia \\ K Lee \\ Universiti Putra Malaysia \\ PY Lim \\ Universiti Putra Malaysia
}

\section{Research Article}

Keywords: Knowledge, Skills, Nurses, CPR, Training, Systematic review

Posted Date: October 28th, 2021

DOI: https://doi.org/10.21203/rs.3.rs-951043/v1

License: (c) (i) This work is licensed under a Creative Commons Attribution 4.0 International License. Read Full License 


\section{Abstract \\ Introduction:}

Although millions of healthcare providers and lay providers are trained globally in CPR each year, there are major gaps in delivering adequate medical emergency care such as poor quality CPR in the hospitals or none performance of CPR in out of hospital settings for people with cardiac arrest.

\section{Objective}

This systematic review aim to highlight the effect of training on knowledge and skills retention as well as the effect of different methods of training on knowledge and skills

\section{Methods}

The review used six online databases: Scopus, ProQuest, PubMed, ScienceDirect, CINAHL, Medline and reviewed reference citations for additional studies. Systematic analysis was use in excluding articles from the database by the latest 2015 American Heart Association (AHA) guidelines, known as Grading of Recommendations, Assessment, Development and Evaluation (GRADE) for the evaluation of knowledge and skills retention.

\section{Results}

A total of 71,671 possible articles were registered in six databases, with 331 articles found meeting eligibility criteria. And only 20 were finally included that met all the qualifying criteria for this systemic analysis. Most research used multi-choice questionnaires to assess retention of both knowledge and skills. From the pretest to the posttest, studies have shown that knowledge or skill rates differ and decrease from 6 weeks to 2 years after training. Between the reviewed papers, significant variations in retaining knowledge and skills were found between instructor-led training and other forms of teaching methods.

\section{Conclusion}

Between the pre-test and post-test outcomes, knowledge and skills have shown a substantial overall improvement in acquisition and retention. However, skills were observed to decay faster than knowledge. Skills start to decay as early as 2 weeks whereas knowledge retention start to decline on average between 1 month and 6 month after BLS/CPR training. Most of the articles showed that other forms of teaching methods are also as effective as the instructor led/traditional teaching methods in knowledge and skills levels among nurses. Therefore, future research should concentrate on the ideal timeline needed after initial training for the re-certification of the BLS/CPR.

\subsection{Background}

Cardiopulmonary resuscitation (CPR) is the primary management for any patient with cardiac arrest. Numerous research centered on the ability of each trainee to apply the learned skills and knowledge gained through training over time while a patient undergoes CPR ((1). After the first training course, participants usually received CPR certification. Subsequently, they will need to renew their certification every two years to remain certified and to retain or update their knowledge and skills in performing CPR $(2,3)$. However, only a handful of trainees are typically able to practice their CPR knowledge and skills in actual clinical situations. Therefore, acquired knowledge and skills are taught, lost, and re-learned after two years. CPR training's primary aim is to show how a learner can successfully resuscitate patients with cardiac arrest by combining applied cognitive knowledge, psychomotor skills, and interpersonal interaction in real hospital settings. Using the skills they learned while confronting a resuscitation situation, learners will develop self-confidence (4). Although the ability of nurses to undertake CPR could be a crucial indicator of cardiac arrest patient survival, there is convincing evidence suggesting that registered nurses across continents lack the ability to perform proper CPR. It is clear from the literature that the skills of the CPR cannot be easily acquired or retained by nurses (5).

Nevertheless, CPR seeks to save a life; therefore, there is a robust link between the degree of CPR knowledge and skills training received by healthcare professionals and the result of survival outcome among cardiac arrest patients (6). As a critical determinant of improved CPR outcome, nurses' knowledge is significantly correlated with their level of CPR training (7). The results of a study in Tanzania showed a significant difference in the overall performance on testing knowledge and skills between those who had and had not performed CPR in the past, with median test scores of 40\%(IQR 28-54) and $26 \%($ IQR $16-42)$ respectively $(p=0.001)(8)$. A similar cross sectional study in Nigeria demonstrated there is statistically significant changes of theoretical knowledge of CPR among clinical medical students with past CPR experience compared to those without CPR experience (P < 0.001) (9). Similarly, a number of variables that can also affect the level of acquisition and retention of the knowledge and skills of nurses have been demonstrated, such as age $(10,11)$ gender $(12,13,14)$ academic qualification $(15)$, clinical experience $(16,17,18)$ timing of training $(19)$, methods of training $(20,21)$ and primary working unit of nurses (22).

CPR training is crucial to nurses, and undeniably the methods of delivery could affect the level of retention of knowledge and skill of CPR among nurses (23). Instructor led training method, otherwise, refer to as traditional CPR training, have been practice for over 40 years. Nonetheless, there is evidence to show that this method of CPR training has failed to achieve the desired result in the retention of knowledge and skills level delivered to both lay people and 
health care providers (20). There is growing evidence that supports the application of alternative methods instead of traditional method of CPR training, such as self-directed training methods with practical skills modules $(11,24,25)$ simulation method $(26,27)$, concept mapping $(28)$ as well as online computers or CD video $(24,29)$.

Effective resuscitation training for busy health care providers may be a challenge. Time and cost for the instructor led CPR, and AED training certification may discourage individuals, private and public organizations from participating in CPR courses and obtaining requisite skills (25). Furthermore, if the instructors did not teach CPR course in a uniform way, this may contribute to the poor retention of CPR skills among students (30). Some studies have shown significant differences in effectiveness between the instructor-led training and others such as self-directed method (5, 11, 24), while, others reported there was no statistically significant difference on performance total score (skill score) between two groups $(21,31,32,33)$.

The purpose of this systematic review is therefore to examine the present evidence for the level of acquisition and retention of knowledge and skills of nurses in CPR and the implications of training strategies towards nurses' CPR knowledge and skills. Most resuscitation organizations recommended a CPR refresher training after two year. It is not clear, however whether CPR-trained nurses can sustain an appropriate level of knowledge and skills suitable for patient care over the two-year intervals. Yet, more frequent practical training would appear to increase the workload on both trainees and instructors at a period when resources and time are required to train healthcare professionals.

\subsection{Materials And Methods}

This systematic analysis was performed in conjunction with the latest 2015 AHA guidelines, as translated from the evidentiary review phase of the International Liaison Committee on Resuscitation (ILCOR), defined as the Grading of Recommendations, Assessment, Development and Evaluation (GRADE). These included studies from January 2013 to December 2019. The research used six online databases: Scopus, ProQuest, PubMed, ScienceDirect, CINAHL, Medline and reviewed reference citations for additional studies.

\subsection{Criteria for eligibility}

The criteria followed for this systematic analysis are as follows: CPR training articles on knowledge and skills applicable to nursing, English articles written and available in full text, both observational and interventional studies, articles with a shared sample audience of nurses and nursing, and keyword articles as illustrated in the table below. Keywords included in this study were: "knowledge OR awareness OR information" OR "skills OR ability OR expertise" AND "nurses OR nursing" AND "cardiopulmonary resuscitation OR CPR OR basic life support OR BLS OR resuscitation."(Table 1)

\subsection{Literature selection (screening / eligibility)}

Journals not meeting requirements such as those with an irrelevant title, not published in the English language, summary journal, over six-year publishing duration, as well as literature such as newspaper article, conference or conference text, book, policy report, etc. were all excluded using the filtering method process. From the selected items, the reference lists in each article were checked.

Table 1

\begin{tabular}{|l|}
\hline Knowledge OR Awareness OR Information \\
\hline OR \\
\hline Skills OR Ability OR Expertise \\
AND \\
\hline Nurses OR Nursing \\
\hline AND \\
\hline Cardiopulmonary resuscitation OR CPR OR basic life support OR BLS OR resuscitation \\
\hline
\end{tabular}

First, two reviewers reviewed title, overlapping subjects, and irrelevant domain subject and information focused on inclusion and exclusion criteria (SA and LPY). The second review team (SA and KT) then screened articles abstracts, followed by full articles content.

Six databases, hand search and references reported a total of 71,671 potentials articles and excluded 59,909 based on inclusion and exclusion criteria (Figure 1). Of 11,702 articles have been excluded, where 6,810 were irrelevant, 1,150 with irrelevant sample populations, and 3,411 with duplicated information. This screening process yielded 331 articles that matched the eligibility requirements and was further screened for the full text. Of the total, 208 did not relate to CPR knowledge and skills, and 103 articles did not specifically identify the sample group, such as a mixed population were excluded. Therefore, 20 studies met all qualifying requirements for this systematic study.

Figure 1. Flowchart of the review process.

\subsection{Data extraction summary}

A total of 13 articles were reported on knowledge among nurses in the review. Four of the articles are RCTs, while three consists of quasi-experimental designs, four articles use prospective repeated measures, and, two use descriptive cross-section studies. Three out of the 13 articles assessed respondents at one point in time $(29,34,29)$ two examined at two points in time on each question $(36,37)$ and the other eight papers examined more than two points in 
time $(11,13,26,28,38,39,40,41)$. A total of 18 articles reported on the skills of nurses. Six of the articles are RCTs, eight are quasi-experimental and four are prospective repeated measures. Only one article out of the 18 articles assessed respondents at one point in time (29), whereas two articles examined respondents at two points in time $(36,37)$ and the remaining other 15 papers examined more than two points in time $(11,13,24.26,27,28,38,39,40,41$, $42,43,44,45,46)$.

Several types of knowledge questionnaire were used in all 13 papers to collect data for the knowledge of participants. Five studies used the AHA questionnaire $(13,26,28,29.39)$, seven studies used self-constructed questionnaires $(11,34,35,37,38,40,41)$ and one study used Resuscitation Council of South Africa (RSCA) qusetionnaire (36). Checklist was used for skill test by evaluators in 11 out 18 articles to records the skill scores during data collection by using the Laerdal manikins. Four articles used skill meter attached to the manikin $(26,39,44,46)$ and the remaining three articles used video to records the scores of the participants $(27,41,45)$.

\subsection{Quality assessment of the literature}

A 2015 guideline recommendation used the current edition of AHA definitions for evidence level and guidance class. Evidence level is as follows; 'LOE A' is high-quality evidence from more than one RCTs; 'LOE B (randomized)' is moderate-quality evidence from one or more RCTs; 'LOE B-NR (nonrandomized)' is moderate-quality evidence from one or more well-designed, well-executed nonrandomized studies or observational studies; "LOE C-LD (limited data)' is a randomized or nonrandomized observational study with limitations of design or execution; "LOE C- EO (expert opinion)" is a consensus of expert opinion based on clinical experience (.47).

The recommendation class is the strength of treatment or training that benefits patients or learners and graded as follows; for example "Class 1 (strong)", such as strategy A is recommended/indicated in preference to treatment B the benefit is three folded than the risk; "Class lla (moderate)", such as strategy A is possibly recommended/indicated in choice to treatment B the benefit is two folded than the risk; "Class Ilb (weak)", such as effectiveness is unknown/unclear/uncertain or not well-established than B or the benefit is equal or more than the benefits; "Class III No Benefit / Moderate", such as strategy A equals B and equal benefits. "Class III harm / strong strategy A harms B more than the benefit (48).

Table 2

Summary of levels of evidence and class of recommendation in training CPR.

\begin{tabular}{|c|c|c|c|c|c|}
\hline \multirow{2}{*}{$\begin{array}{l}\text { Class of } \\
\text { recommendation } \\
\text { (COR) }\end{array}$} & \multicolumn{5}{|c|}{ Level of Evidence } \\
\hline & $\begin{array}{l}\text { Level } \\
\text { A }\end{array}$ & Level B - R & Level B-NR & Level C- LD & $\begin{array}{l}\text { Level C- } \\
\text { EO }\end{array}$ \\
\hline \multicolumn{6}{|l|}{ Class 1 (strong) } \\
\hline $\begin{array}{l}\text { Class 11a } \\
\text { (moderate) }\end{array}$ & & (Saiboon et al., 2016) 11 & & & \\
\hline \multirow[t]{2}{*}{$\begin{array}{l}\text { Class 11b } \\
\text { (weak) }\end{array}$} & & \multirow[t]{2}{*}{$\begin{array}{l}\text { (Hernández-Padilla et al., 2015)41 } \\
\text { (Serwetnyk et al.,2015)29 (Anderson et } \\
\text { al.,2019)46 (Aqel \& Ahmad, 2014)26 }\end{array}$} & $\begin{array}{l}\text { (Saramma et al., 2016)37 } \\
\text { (Mardegan et al., 2015)24 }\end{array}$ & $\begin{array}{l}\text { (Munezero et al., 2018)36 (Niles } \\
\text { et al., 2017) } 44 \text { (Chen et al., } \\
\text { 2018)27 }\end{array}$ & \\
\hline & & & $\begin{array}{l}\text { (Toubasi etal.,2015)42 } \\
\text { Terzi et al., 2017)43 } \\
\text { (Rajeswaran et al.,.2018) } \\
13\end{array}$ & $\begin{array}{l}\text { (Sullivan et al., 2015) } \\
45(\text { Bajracharya } \\
\text { \&Nagarkoti.,2016)34 } \\
\text { (Aliyari et al., 2019)28 } \\
\text { (Shahrakivahed et al., 2015)38 } \\
\text { (Partiprajak \& Thongpo, 2016)39 }\end{array}$ & \\
\hline $\begin{array}{l}\text { Class } 111 \text { No } \\
\text { benefit } \\
\text { (moderate) }\end{array}$ & & & & (Yılmaz \& Simsek, 2019)40 & $\begin{array}{l}\text { (Vural et } \\
\text { al., } \\
2017) 36\end{array}$ \\
\hline \multicolumn{6}{|l|}{$\begin{array}{l}\text { Class } 111 \text { Harm } \\
\text { (strong) }\end{array}$} \\
\hline
\end{tabular}




\begin{tabular}{|c|c|c|c|c|c|c|c|c|}
\hline \multicolumn{9}{|c|}{ Knowledge among nurses following cardiopulmonary resuscitation (CPR) training. } \\
\hline $\begin{array}{l}\text { Study (year } \\
\text { published) }\end{array}$ & $\begin{array}{l}\text { Hosp. setting / } \\
\text { Duration }\end{array}$ & $\begin{array}{l}\text { Study } \\
\text { design/ } \\
\text { Study } \\
\text { population }\end{array}$ & $\begin{array}{l}\text { Teaching } \\
\text { method }\end{array}$ & $\begin{array}{l}\text { Participants } \\
\text { Retention } \\
\text { rate }\end{array}$ & $\begin{array}{l}\text { Evaluation } \\
\text { methods }\end{array}$ & Pretest score & $\begin{array}{l}\text { Posttest } \\
\text { score }\end{array}$ & Follow-up \\
\hline $\begin{array}{l}\text { (Serwetnyk et } \\
\text { al., 2015) }\end{array}$ & Tertiary/1 day & $\begin{array}{l}\text { RCT } \\
\text { Registered } \\
\text { Nurse } \\
(n=220)\end{array}$ & $\begin{array}{l}\text { Instructor-led } \\
\text { (control } \\
\mathrm{n}=46) \text { vs } \\
\text { Online } \\
\text { computer } \\
\text { base } \\
\text { (Intervention } \\
\mathrm{n}=45) \text { vs } \\
\text { HeartCode } \\
\text { (Intervention } \\
\mathrm{n}=79)\end{array}$ & $77 \%$ & $\begin{array}{l}\text { AHA BLS for } \\
\text { Healthcare } \\
\text { Provider } \\
\text { posttest } \\
\text { (Versions C } \\
\text { and D for } \\
\text { remediation)/ } \\
\text { Online } \\
\text { posttest/ } \\
\text { Virtual practice } \\
\text { and testing } \\
\text { using } \\
\text { eSimulation } \\
\text { technology }\end{array}$ & Not reported & $\begin{array}{l}\text { Heart code } \\
79 \% \text { Pass } \\
\text { BLS online } \\
95 \% \text { Pass } \\
\text { Instructor } \\
\text { led } 98 \% \\
\text { Pass } \\
(p=002)\end{array}$ & Not reported \\
\hline $\begin{array}{l}\text { (Aqel \& Ahmad, } \\
\text { 2014) }\end{array}$ & $\begin{array}{l}\text { University } \\
\text { student } 1 \text { day }\end{array}$ & $\begin{array}{l}\text { RCT } \\
\text { Student } \\
\text { nurses } \\
(n=124)\end{array}$ & $\begin{array}{l}\text { Instructor led } \\
\text { group as } \\
\text { (Control Low } \\
\text { fidelity } \\
\text { simulation) } \\
\text { Intervention } \\
\text { (High fidelity } \\
\text { simulation) }\end{array}$ & $72 \%$ & $\begin{array}{l}\text { Multiple choice } \\
\text { questions on } \\
\text { CPR } \\
\text { knowledge } \\
\text { (American } \\
\text { Heart } \\
\text { Association } \\
\text { [AHA], 2012). }\end{array}$ & $\begin{array}{l}\text { Mean score } \\
\text { for } \\
\text { Control is } \\
5.93 \pm 1.15 \\
\text { Intervention } \\
\text { is } 5.78 \pm 1.18\end{array}$ & $\begin{array}{l}\text { Mean score } \\
\text { after } \\
\text { training } \\
\text { Control is } \\
11.22 \pm 0.90 \\
\text { Intervention } \\
\text { is } \\
12.67 \pm 1.06\end{array}$ & $\begin{array}{l}\text { At three } \\
\text { months } \\
\text { Control is } \\
10.0 \pm 1,44 \\
\text { Intervention is } \\
12.2 \pm 1.14 \\
P \leq .001\end{array}$ \\
\hline $\begin{array}{l}\text { (Saiboon et al., } \\
\text { 2016) }\end{array}$ & $\begin{array}{l}\text { Tertiary/7 } \\
\text { days }\end{array}$ & $\begin{array}{l}\text { RCT/ (TCI } 39 \\
\text { nurses \& SIV } \\
41 \text { nurses). } \\
\text { Registered } \\
\text { Nurse }(n=80)\end{array}$ & $\begin{array}{l}\text { Instructor-led } \\
\text { (TCI) vs Self- } \\
\text { directed } \\
(\mathrm{SIV})\end{array}$ & $30 \%$ & $\begin{array}{l}\text { Multiple choice } \\
\text { questions on } \\
\text { AED } \\
\text { knowledge } \\
\text { (self- } \\
\text { constructed) }\end{array}$ & $\begin{array}{l}\text { Mean score } \\
\text { for } \\
\text { Instructor-led } \\
\text { (TCI) } 10.87 \\
\text { Self-directed } \\
\text { (SIV) } 10.37 \\
(P=0.29)\end{array}$ & $\begin{array}{l}\text { After } \\
\text { training; } \\
\text { mean score } \\
\text { for } \\
\text { Instructor } \\
\text { led TCl } \\
13.22 \\
\text { Self-directed } \\
\text { SIV } 12.91 \\
(P=0.52)\end{array}$ & $\begin{array}{l}\text { At six months; } \\
\text { mean score } \\
\text { Instructor led } \\
\text { TCl } 11.13 \\
\text { Self-directed } \\
\text { SIV } 12.95 \\
(P=0.03)\end{array}$ \\
\hline $\begin{array}{l}\text { (Hernández- } \\
\text { Padilla et al., } \\
\text { 2015) }\end{array}$ & $\begin{array}{l}\text { university/1 } \\
\text { day }\end{array}$ & $\begin{array}{l}\text { RCT } \\
\text { Student } \\
\text { nurses } \\
(n=177)\end{array}$ & $\begin{array}{l}\text { Instructor-led } \\
\text { ( control n= } \\
\text { 89) \& } \\
\text { student- } \\
\text { directed } \\
\text { (Intervention } \\
\mathrm{n}=88 \text { ) } \\
\text { training }\end{array}$ & $87 \%$ & $\begin{array}{l}\text { Multiple choice } \\
\text { questions on } \\
\text { CPR } \\
\text { knowledge } \\
\text { (self- } \\
\text { constructed) }\end{array}$ & $\begin{array}{l}\text { Instructor-led } \\
65 \% \\
\text { Student- } \\
\text { directed } 64 \%\end{array}$ & $\begin{array}{l}\text { After } \\
\text { training } \\
\text { Instructor- } \\
\text { led } 90 \% \\
\text { Student- } \\
\text { directed } \\
99 \%\end{array}$ & $\begin{array}{l}\text { At three } \\
\text { months } \\
\text { Instructor-led } \\
80 \% \\
\begin{array}{l}\text { Student- } \\
\text { directed } 99 \% \\
(P<0.001)\end{array}\end{array}$ \\
\hline $\begin{array}{l}\text { (Shahrakivahed } \\
\text { et al., 2015) }\end{array}$ & $\begin{array}{l}\text { Tertiary/ } 3 \\
\text { days }\end{array}$ & $\begin{array}{l}\text { Quasi - } \\
\text { experimental } \\
\text { Registered } \\
\text { nurses } \\
(n=140)\end{array}$ & Instructor led & $98 \%$ & $\begin{array}{l}\text { Multiple choice } \\
\text { questions on } \\
\text { CPR } \\
\text { knowledge } \\
\text { (self- } \\
\text { constructed) }\end{array}$ & $\begin{array}{l}\text { Mean score } \\
21 \pm 85.9\end{array}$ & $\begin{array}{l}\text { After } \\
\text { training } \\
\text { Mean score } \\
41 \pm 25.12\end{array}$ & $\begin{array}{l}\text { After three } \\
\text { months } \\
\text { Mean score of } \\
5.45 \pm 36.14 \\
P=0.001\end{array}$ \\
\hline $\begin{array}{l}\text { (Rajeswaran et } \\
\text { al., 2018) }\end{array}$ & Tertiary/1 day & $\begin{array}{l}\text { Quasi- } \\
\text { experimental } \\
\text { Registered } \\
\text { Nurse } \\
(n=154)\end{array}$ & Instructor-led & $55 \%$ & $\begin{array}{l}\text { Multiple choice } \\
\text { questions on } \\
\text { CPR } \\
\text { knowledge } \\
\text { (American } \\
\text { Heart } \\
\text { Association } \\
\text { [AHA], 2010). }\end{array}$ & $\begin{array}{l}\text { Mean score } \\
48.15 \pm 17.02\end{array}$ & $\begin{array}{l}\text { Mean score } \\
\text { after } \\
\text { training } \\
74.16 \\
\pm 13.24 \\
P<0.001\end{array}$ & $\begin{array}{l}\text { Mean score at } \\
\text { six months } \\
59.7\end{array}$ \\
\hline
\end{tabular}




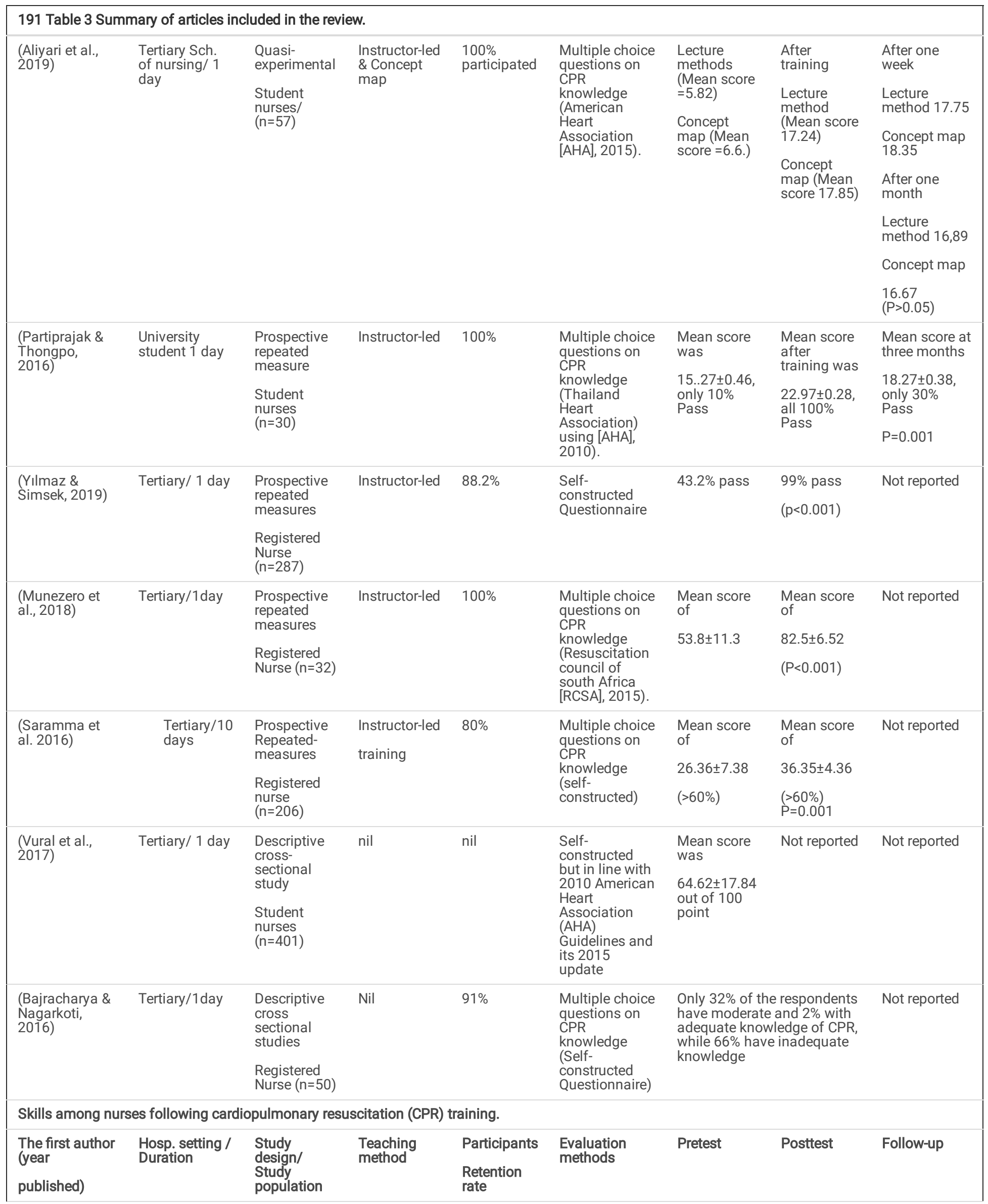




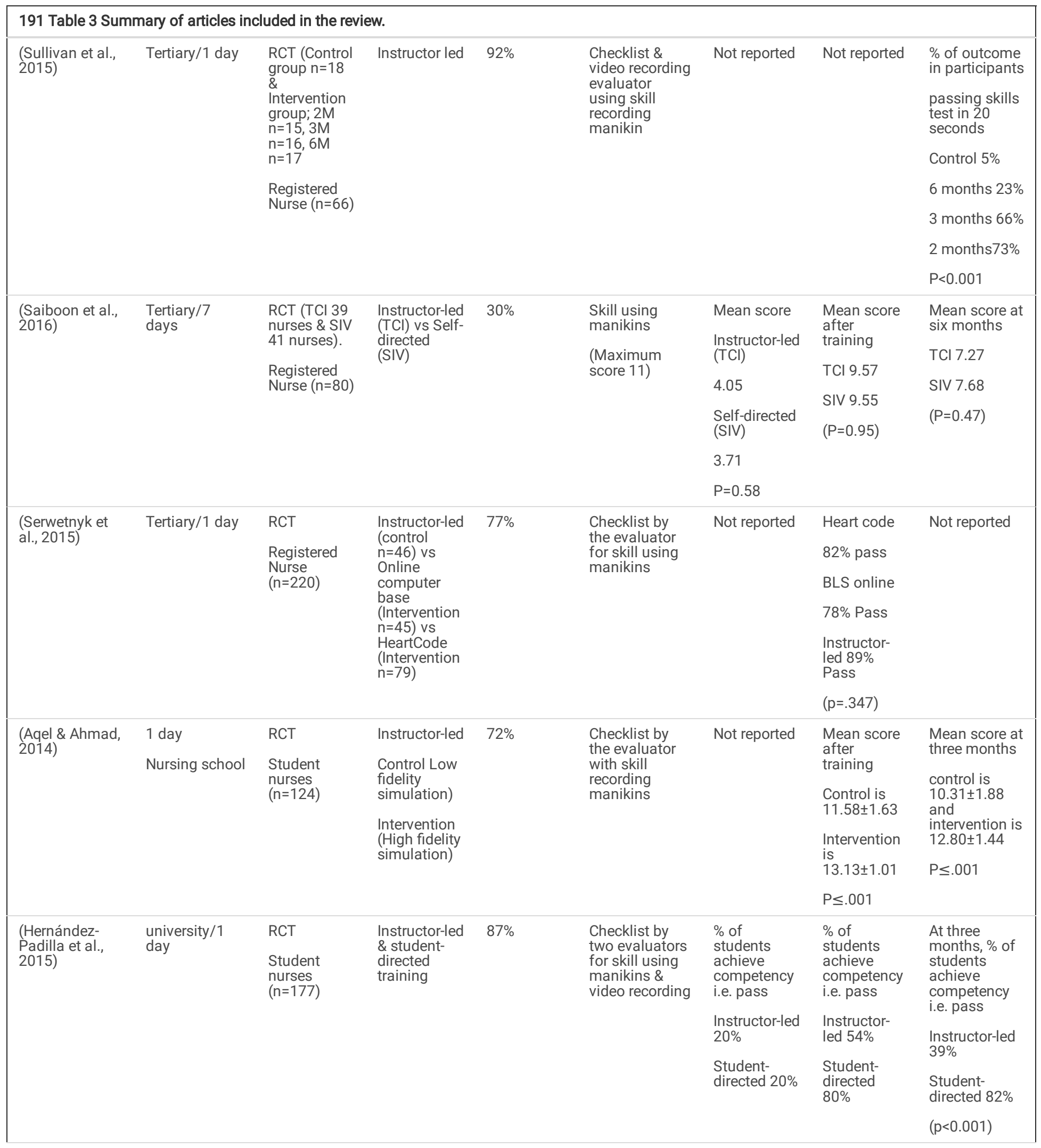




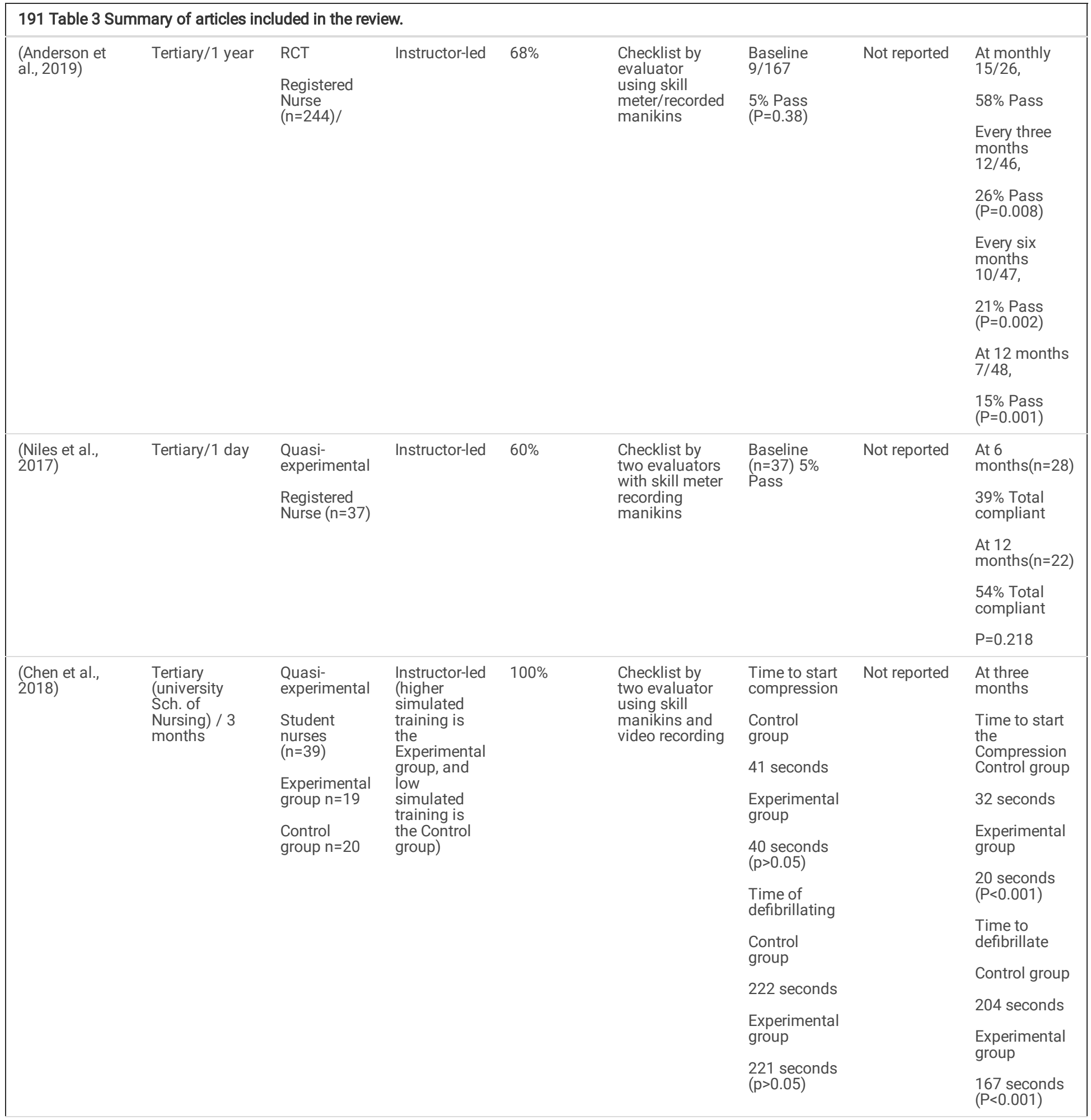




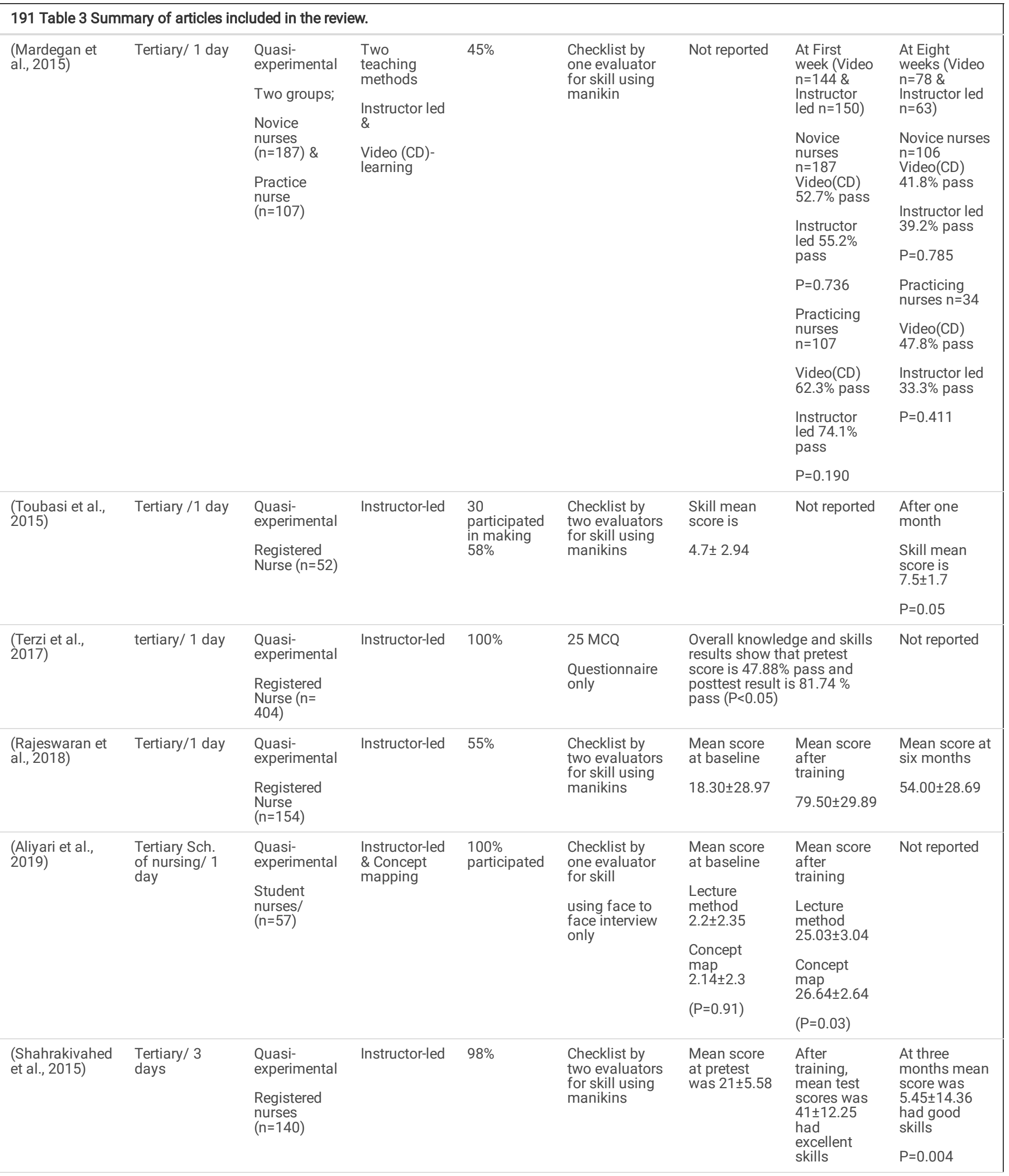




\begin{tabular}{|c|c|c|c|c|c|c|c|c|}
\hline \multicolumn{9}{|c|}{191 Table 3 Summary of articles included in the review. } \\
\hline $\begin{array}{l}\text { Saramma et al. } \\
(2016)\end{array}$ & $\begin{array}{l}\text { Tertiary/10 } \\
\text { days }\end{array}$ & $\begin{array}{l}\text { Prospective } \\
\text { Repeated- } \\
\text { measures } \\
\text { Registered } \\
\text { nurse } \\
\text { ( } n=206\end{array}$ & $\begin{array}{l}\text { Instructor-led } \\
\text { simulation }\end{array}$ & $80 \%$ & & Not reported & $\begin{array}{l}\begin{array}{l}\text { Mean score } \\
\text { of }\end{array} \\
40.39 \pm 4.32 \\
(>80 \%) \\
(P=0.001)\end{array}$ & $\begin{array}{l}\text { After two } \\
\text { years mean } \\
\text { score of } \\
3.59 \pm 1.99 \text { of } \\
\text { certified } \\
\text { nurse's vs. } \\
3.19 \pm 1.93 \text { of } \\
\text { non-certified } \\
\text { nurse's } \\
P=0.426\end{array}$ \\
\hline \multirow[t]{2}{*}{$\begin{array}{l}\text { (Munezero et } \\
\text { al., 2018) }\end{array}$} & \multirow[t]{2}{*}{ Tertiary/1day } & \multirow{2}{*}{$\begin{array}{l}\text { Prospective } \\
\text { repeated } \\
\text { measures } \\
\text { Registered } \\
\text { Nurse }(n=32)\end{array}$} & \multirow[t]{2}{*}{ Instructor-led } & \multirow[t]{2}{*}{$100 \%$} & $\begin{array}{l}15 \text { point skill } \\
\text { question }\end{array}$ & $\begin{array}{l}\text { Mean score } \\
\text { of }\end{array}$ & $\begin{array}{l}\text { Mean score } \\
\text { of }\end{array}$ & \multirow[t]{2}{*}{ Not reported } \\
\hline & & & & & $\begin{array}{l}\text { Checklist by } \\
\text { one evaluator } \\
\text { for skill using } \\
\text { manikins }\end{array}$ & $46 \pm 17.01$ & $\begin{array}{l}81.5 \pm 6.79 \\
(P=0.02)\end{array}$ & \\
\hline $\begin{array}{l}\text { (Yllmaz \& } \\
\text { Simsek, 2019) }\end{array}$ & Tertiary/ 1 day & $\begin{array}{l}\begin{array}{l}\text { Prospective } \\
\text { repeated } \\
\text { measures }\end{array} \\
\text { Registered } \\
\begin{array}{l}\text { Nurse } \\
(\mathrm{n}=287)\end{array}\end{array}$ & Instructor-led & $95.5 \%$ & $\begin{array}{l}\text { Checklist by } \\
\text { one evaluator } \\
\text { for skill using } \\
\text { manikins }\end{array}$ & \multicolumn{3}{|c|}{$\begin{array}{l}\text { The result shows a combine overall knowledge } \\
\text { and skills scores of pretest } 43.2 \% \text { and posttest } \\
\text { score } 99 \% \text { pass } \mathrm{P}<0.001\end{array}$} \\
\hline $\begin{array}{l}\text { (Partiprajak \& } \\
\text { Thongpo, } \\
\text { 2016) }\end{array}$ & 1 day & $\begin{array}{l}\text { Prospective } \\
\text { repeated } \\
\text { measures } \\
\text { Student } \\
\text { nurses } \\
(n=30)\end{array}$ & Instructor-led & $100 \%$ & $\begin{array}{l}\text { Checklist by } 1 \\
\text { evaluator } \\
\text { using skill } \\
\text { recording } \\
\text { manikins }\end{array}$ & Not reported & $\begin{array}{l}\text { After } \\
\text { training } \\
\text { mean score } \\
\text { was } \\
11.67 \pm 7.91\end{array}$ & $\begin{array}{l}\text { At three } \\
\text { months mean } \\
\text { score was } \\
8.33 \pm 4.61 \\
(P=0.451)\end{array}$ \\
\hline
\end{tabular}

\subsection{Results}

\subsection{Acquisition and retention of knowledge after CPR training}

13 articles in this systematic analysis of study recorded knowledge outcomes after CPR training. The research population comprises of registered nurses (eight articles) and student nurses (five articles). Ten studies have been conducted in the tertiary hospital setting and three in the educational environment, such as the university nursing school. An average of one-day training, consisting of either pre-test, post-test, or follow-up evaluation methods, was carried out in 10 out of 13 studies included in this analysis. It should be noted that the quality of each article in the review in terms of level of evidence (LOE) and a class of recommendation (COR) is rated independent of each other, therefore any COR can be paired with any LOE. None of the 13 articles fulfill the Level A LOE requirements. Likewise, none of the 13 studies come under COR Guideline Class I (strong benefits) and Class III (strong harm).

In this review, knowledge level acquisition and retention studies have a total sample size of 1,958 respondents with a minimum sample size of 30 and a maximum sample size of 401 . Eleven of the 13 studies utilized instructor-led teaching methods. Nine articles had more than $75 \%$ of the response rate of participants. Similarly, out of 13 articles in this review, 11 reported sex and age except studies by Shahrakivahed et al., (2015) and Vural et al., (2017). Women made up the majority of respondents in 12 studies except in a study by Aliyari et al., (2019). Among the eight studies that involves registered nurses' population, only two studies included majority of graduates among professional nurses, and the other six are all having diploma certificates. Years of nursing practice in eight studies range from 2 to 25 years.

A significant progress in knowledge scores from pretest compared to posttest was found in the four studies with $P$ value of $<0.05$, such as in Rajeswaran et al., (2018) recorded a mean total score of $48.15 \%$ in pretest rise to $74.16 \%$ posttest and decline to $59.7 \%$ at the end of six months $(P<0.001)$; Saramma et al., (2016) reported knowledge performance at pretest as 35.5\% and posttest as $93.4 \%(P=0.001)$; Munezero et al., (2018) also recorded a knowledge average score of $53.8 \%$ at pretest and $82.5 \%$ at posttest $(P=0.001)$; Y Ilmaz \& Simsek (2019) marked a combined overall rating of $43.2 \%$ for pretest knowledge and skills and $99 \%$ for posttest $(P<0.001)$. It can be concluded that there was increased in knowledge after the training.

Another three studies measured the efficacy of self-directed (video, CD/DVD, simulation) versus instructor-led teaching methods, showing an improvement in the score differences between pretest and posttest and/or follow-up test scores. Saiboon et al., (2016) reported a six-month follow-up with a significant difference in comparison between the Instructor-led group scoring $11.13 \pm 2.70$ compared to $12.95 \pm 2.26$ of the self-instructor video ( $P=0.03$ ). Similarly, Hernández-Padilla et al., (2015) study also showed that there were significant variances in the knowledge score obtained during the instructor-led pretest at $65 \%$ and $90 \%$ after training and $80 \%$ after three months. Likewise, the student-directed knowledge score obtained at pretest was at $64 \%$ and $99 \%$ at posttest and $99 \%$ at the end of three months $(\mathrm{P}<0.001)$. Aliyari et al., (2019) conducted a comparative one-month follow-up study between instructor-led and concept map training method which confirmed the session effectiveness of the two methods and the result showed significant changes were found between the mean scores of knowledge of the two methods i.e. instructor-led at pretest were 5.82 and one month at $17.24(P<0.001)$ and concept map pretest at 6.6 and one months at $17.85(P<0.001)$. However, the comparison of mean scores of knowledge was not statistically significant in the two groups in the post-test $(P$ $>0.05)$. 


\subsection{Acquisition and retention of skills after CPR training}

Eighteen studies reported on skills outcomes during CPR training in this systematic review study. The study population is the registered nurses (13 articles) and student nurses ( 5 articles). 13 studies were done in the tertiary hospital setting and five were in the educational environment, such as the university nursing school. Fourteen articles used a one-day training period, while the remaining four used between three to seven days and all of them comprising either on pretest, posttest or follow-up. The review on level of acquisition and retention of skills have a combined sample size of 1,422 respondents with 37 minimum sample size and 404 maximum sample size. All eighteen papers use instructor-led assessment approaches. Eleven studies had a participant's response rate above 75\%. All articles except Shahrakivahed et al., (2015) reported sex and age. Women made up most respondents except in a study by Aliyari et al., (2019). Twelve articles have a representative population of registered nurses, and only one article has graduate nurses as the participants in the study (44). Years of work experience for registered nurses in 15 studies range from 2 to 25 years, averaging $8.5 \pm 1.37$ years. Most respondents come from medical or surgical wards in hospitals where they work.

Of the 18 articles evaluating the skills of the participants, only six tested skills only $(24,27,42,44,45,46)$ and were evaluated in their assessment procedures, while the remaining 12 articles $(11,13,26,28,29,36,27,38,39,40.41,43)$ examined both knowledge and skills. Three out of six studies found a correlation for deliberate practice between the participant's pretest, posttest, and follow-up training score, implying that the more you practice, the greater the retention of skills. Anderson et al., (2019) reported results among 167 nurses over 12 months study period. In the study, respondents who were trained monthly had a significantly higher proportion of excellent CPR performance (58\%) than those training every 3 month (26\%), training every 6 month (21\%) and training every 12 month (15\%) $(\mathrm{P}<0.001)$. Sullivan et al. (2015) also reported a study among 66 non-intensive unit nurses, that showed a significant differences in improved skills within the experimental groups (control: six months: $23 \%$ vs. three months: $56 \%$ vs. 2 months: $73 \%, P<0.001$ ).

There were significant improvements in chest compression quality after Rolling Refreshers (RRs) were implemented, according to Niles et al. (2017); odds ratios for meeting criteria were 35.1 ( $95 \%$ confidence interval $=2.5496, \mathrm{P}=0.009$ ) and $22.3(95 \%$ confidence interval $=2.1239, \mathrm{P}=0.010)$. $\mathrm{A}$ comparison of chest compression quality at 12 months and 6 months of RR did not reveal any differences in chest compression quality. After traditional basic life support recertification, Niles concludes that chest compression psychomotor skill quality can only be retained for six months. While two studies showed the impact of simulation to skills acquisition and retention level. Toubasi et al., (2015) reported also in their studies of 30 registered nurses, the result also showed an association between pretest mean score 4.6 and posttest outcomes mean score 7.5 with an overall improvement in skills and BLS scores after simulation testing $(P<0.001)$. Chen et al., (2018) showed a statistically significant difference in decreased median (interquartile ranges, IQR) seconds among participants with decreased response time in a resuscitation simulation. At the beginning of the course to start compression: control group (CG) 41(32-49) vs. experimental group (EG) $42(33-46)(P>0.05)$ and defibrillation (CG $222(194-254)$ vs. EG $221(214-248)(P>0.05)$ compared with the end of the course to start compression (CG $32(25-75)$ vs. EG 20 (18-38) $(P<0.001)$ and defibrillation (CG 204 (174-240) vs. EG 167 (162-174) (P< 0.001$)$.

Study by Mardegan et al., (2015) on the impact of self-directed learning on skills acquisition and retention level showed that there were no statistically significant differences between video and instructor-led training among novice nurses and practicing nurses in the first week $(P=0.190)$ and the eight weeks post-testing $(\mathrm{P}=0.411)$.

\section{Discussion}

\subsection{Knowledge among nurses following cardiopulmonary resuscitation (CPR) training.}

In all 13 studies in this analysis, four uses repeated measures, while three are quasi-experimental research designs and four were randomized controlled trials. All these design uses tools that reduces bias and examine cause-effect relationships which is good at answering the question about knowledge level and retention among the nurses in this study. Equally, 11 out of 13 articles have a sample size of less than 200, ranging from $28-177$ people, involving a single institution in hospitals or nursing schools.

The findings of 10 articles in this analysis demonstrated the impact of CPR training in acquiring CPR knowledge level among nurses, comparing the level of knowledge acquired before training (pre-test) to significant level of knowledge acquired after training (post-test). (11,13,26,28, 36,37. 38, 39,40,41). Similar studies have been recorded between the pre-and post-tests performance by $(5,16,52)$ that support the vital role of CPR training in ensuring that nurses are skilled, up-to-date and confident in the event of cardiac arrest.

On the other hand, seven articles in this review also reported on the retention of CPR/BLS knowledge level on critical skills after the post training test. Their result also showed a gradual decline in knowledge retention among nurses after the post training test which appears to occur, on average between 1 months and 6 month after CPR training (one month - 28, three months- $26,38,39,41$ and six months- 11, 13). The above result is similar to the results of previous studies conducted by $(49,50)$ which looked at CPR knowledge and skills retention. It should be noted that the less frequent an individual updates his or her knowledge, the lower the retention of knowledge/skills is expected, as theoretical knowledge and skills tend to decline over time (51, 52). It is therefore suggested that training and retraining of CPR participants should be carried out at least within six months for all health professionals instead of the recommended 2-year period, as outlined in the 2015 ILCOR recommendation, and should be in keeping with the reality of each hospital training needs or environments.

Four studies in this review compared two different CPR/ BLS teaching methods among nurses between the instructor-led as a control group and others, such as video self-directed, concept map, student-directed and high-fidelity simulation as intervention group $(11,26,28,41)$. Although these studies reported only on nurses with a significant difference between the two methods in the acquisition and retention of CPR / BLS knowledge. Two studies by (53, 54) 
reveal a consistent findings with Aqel \& Ahmad et al., (2014) study emphasize the effectiveness of HFS on students' acquisition of knowledge and skills. Similarly, findings by Madden,et al., (2006) also concur that cognitive knowledge of BLS/AED significantly improved after a training session regardless of whether they belonged to the Instructor directed group (IDG) or Student directed group (SDG). However, these findings must be cautiously interpreted with Hernández-Padilla et al., (2015) submission, in which students who had already participated in a BLS/AED training session three months before the intervention and this could have positively influenced their final results in the Madden study.

Equally, studies done by $(5,10,55,56,57,58)$, all confirm the similarity of the results as reported where there is significant difference between pretest and posttest as well as retention test between the two methods in this review. Only one study by (28) reported a contrary view of studies done by (59 60) with regard to concept map training on medical students revealing no significant different between the two methods. Although the duration of time used by Dong was longer, 10 hours instead of 4 hours, while in Cutrer's study, assessment of the knowledge was conducted by plotting 3 concept maps by participants instead of MCQ questions used in Aliyari et al., 2019 analysis. It is therefore suggested that future CPR / BLS training should give participants access to skills labs or training facilities after the initial training period.

\subsection{Skills among nurses following cardiopulmonary resuscitation (CPR) training}

Four study were repeated-measure studies, while eight were quasi-experimental study designs and six were randomized controlled studies. Like most CPR / BLS training, it has been repeatedly shown in many previous studies that skills tend to decline faster than knowledge after CPR training (10, 46). For example, two study results in this review showed a poor level of skills after initial training and follow-up compared to knowledge (13, 36). This is similar to (61) findings in their study, where the skills appear to be declining at a faster rate than knowledge, decreased as early as 2 weeks after training, and up to the pre-training levels by $1-2$ years later. Similar studies by $(62,63,64,6566)$ on varying pace of skills deterioration compared to knowledge was also identified.

On the contrary, four studies in this review reported opposite results where retention of skills was found to be better maintained at post-training than knowledge $(11,24,26,44)$. Two studies among them reported previous half a year professional training in the BLS / CPR course seemed to enhance the actual memory of learning among participants $(24,44)$. Furthermore, two studies by $(6768)$ also revealed a similar conclusion that previous training can enhance skills mastery.

Six articles in this reviewed study that tested skills only, revealed an overall significant increase in skill acquisition and retention between pre-test results and post-test outcomes using a deliberate practice approach $(24,27,42,44,45,46)$. This finding is similar to what has been reported in a study among a group of lay people $(21,69)$. Similarly, all 18 studies that tested skills competency used the checklist as a key instrument for testing skills using the lead manikins, except (43), which opted for the use of the MCQ. Again, six of the 18 articles were evaluated by a single evaluator, while five were evaluated by two teams of evaluators, and the remaining seven use skill recording manikins and video recorders to evaluate the skills of the participants.

While comparing two different CPR/ BLS teaching methods between the instructor-led as a control group and other forms of teaching, such as video selfdirected, concept map, student-directed, and high-fidelity simulation as an intervention group, five studies revealed a significant result in this review. This is comparable to the conclusion reported by (70), which revealed that participants who used a mix of case study and concept map rather than a case study alone had a superior knowledge. According to a study by $(26,49)$, those who have previous cardiac simulation experience learn and retain CPR skills better than those who learn and retain CPR knowledge.

When comparing student and teacher learning techniques, participants' BLS/AED knowledge and skills are observed to decline significantly between posttest and retention-test (41). This is also in line with previous research (71, 72). However, Mardegan et al., (2015) observed no statistically significant changes in BLS skills of novice and practicing nurses at one week and eight weeks after training between CD and traditional instructor led BLS training approaches $(\mathrm{P}=0.41)$.

\section{Limitation}

Included studies that employ quasi-experimental procedures without blinding participants may raise doubts about their dependability, which is one of the drawbacks noted. In the same way, respondents' beliefs could impact the self-reported questionnaires employed in the identified studies.

\section{Conclusions}

Thirteen articles analyzed knowledge of nurses in this study, of which four are repeated studies, three quasi-experimental research designs and four are randomized controlled trials, only two uses cross-section descriptive studies. Likewise, 18 articles reported performance of skills four repeated measures studies, eight quasi-experimental study designs and six are randomized controlled studies. In this analysis, acquisition and retention of knowledge and skills have been shown to significantly increase between pre-test and post test results. However, skills were observed to decay faster than knowledge. Skills start to decay as early as 2 weeks whereas knowledge retention start to decline on average between 1 month and 6 month after BLS/CPR training. Most of the articles showed that other forms of teaching methods are also as effective as the instructor led/traditional teaching methods in knowledge and skills levels among nurses. Future studies should therefore focus on the optimal timeframe required for the re-certification of the BLS/CPR after initial training. This will help to achieve the desired outcome of the reduction of cardiac arrest mortality.

\section{Abbreviations}

CPR: Cardiopulmonary Resuscitation; BLS: Basic life Support; AED: Automated External defibrillator; AHA: American Heart Association 


\section{Declarations}

\section{Acknowledgements}

None.

\section{Funding}

This research did not receive any specific funding from agencies in the public, commercial, or not-for-profit sectors.

\section{Availability of data and materials}

All other datasets supporting the conclusions of this article are included within the article and its additional files.

\section{Authors' contributions}

Saidu Ahmed - Conceptualized the study and performed the literature search.

Saidu Ahmed - Conducted the study selection of all retrieved records by the inclusion and exclusion criteria.

Saidu Ahmed and Lim Poh Ying - Assessed the methodological quality of all included studies.

Saidu Ahmed - Performed the data synthesis.

Lim Poh Ying and Iskasymar Ismail - Reviewed the data synthesis.

Saidu Ahmed - Drafted the manuscript.

Lim Poh Ying, Iskasymar Ismail, and Lee Khuan - Revised the manuscript.

All authors read and approved the final manuscript.

\section{Authors' information}

This systematic review is part of the PhD project of Saidu Ahmed, supervised by LPY, LK and I I.

\section{Ethics approval and consent to participate}

Not applicable.

\section{Consent for publication}

Not applicable.

\section{Competing interests}

The authors declare that they have no competing interest.

\section{Author details}

1 Department of Nursing and Rehabilitation, Faculty of Medicine and Health Sciences, Universiti Putra Malaysia, 43400 UPM Serdang, Selangor, Malaysia.; gs54771@student.upm.edu.my;/asaidu@hotmail.com: leekhuan@upm.edu.my.

2 Department of Medicine, Faculty of Medicine and Health Sciences, Universiti Putra Malaysia, 43400 UPM Serdang, Selangor, Malaysia. iskasymar@upm.edu.my

3 Department of Community Health, Faculty of Medicine and Health Sciences, Universiti Putra Malaysia, 43400 UPM Serdang, Selangor, Malaysia. pohying_my@upm.edu.my_

\section{References}

1. Mutchner L. (2007). The ABCs of CPR-again Am J Nurs. 2007 Jan; 107(1):60-9; quiz 69-70. doi: 10.1097/00000446-200701000-00024.

2. Affecting, M. I., Rescuers, A., Therapies, E., Cardiovascular, A., Support, L., Syndromes, A. C., Basic, P., Support, L., Life, P. A., Resuscitation, N., Issues, E., \& Aid, F. (2010). Hig h lig h t s of th e 2010 American Heart Association Guidelines for CPR and ECC.

3. Mary Fran Hazinski, RN, MSN; Michael Shuster, MD; Michael W. Donnino, MD; Andrew H. Travers, MD, Ms. R., A. Samson, MD; Steven M. Schexnayder, MD; Elizabeth H. Sinz, MD; Jeff A. Woodin, NREMT-P; Dianne L. Atkins, M., Farhan Bhanji, MD; Steven C. Brooks, MHSc, MD; Clifton W. Callaway, MD, PhD; Allan R. de Caen, M. M. E., Kleinman, MD; Steven L. Kronick, MD, MS; Eric J. Lavonas, MD; Mark S. Link, MD; Mary E. Mancini, RN, P. L., J. Morrison, 
MD, MSc; Robert W. Neumar, MD, PhD; Robert E. O’Connor, MD, MPH; Eunice M. Singletary, M. M. H., \& Wyckoff, M. and the A. G. H. P. T. (2015). H I G H L I G H T S of the 2015 American Heart Association Guidelines Update for CPR and ECC. https://doi.org/10.1161/01.CIR.0000019552.77778.04

4. Albert Bandura's. (1986). The social cognitive theory. In Boston University School of Public Health. http://sph.bu.edu/otlt/MPH-Modules/SB/SB721Models/SB721-Models5.html

5. Mokhtari Nori, J., Saghafinia, M., Kalantar Motamedi, M. H., \& Khademolv Hosseini, S. M. (2012). CPR training for nurses: How often is it necessary? Iranian Red Crescent Medical Journal, 14(2), 103-106.

6. Sodhi, K., Singla, M., \& Shrivastava, A. (2011). Impact of advanced cardiac life support training program on the outcome of cardiopulmonary resuscitation in a tertiary care hospital. Indian Journal of Critical Care Medicine, 15(4), 209-212. https://doi.org/10.4103/0972-5229.92070

7. Dane, F. C., Russell-Lindgren, K. S., Parish, D. C., Durham, M. D., \& Brown, T. D. (2000). In-hospital resuscitation: Association between ACLS training and survival to discharge. In Resuscitation (Vol. 47, Issue 1, pp. 83-87). https://doi.org/10.1016/S0300-9572(00)00210-0

8. Kaihula, W. T., Sawe, H. R., Runyon, M. S., \& Murray, B. L. (2018). Assessment of cardiopulmonary resuscitation knowledge and skills among healthcare providers at an urban tertiary referral hospital in Tanzania. BMC Health Services Research, 18(1), 1-8. https://doi.org/10.1186/s12913-018-3725-2

9. Okonta, K., \& Okoh, B. N. (2015). Theoretical knowledge of cardiopulmonary resuscitation among clinical medical students in the University of Port Harcourt, Nigeria. African Journal of Medical and Health Sciences, 14(1), 42. https://doi.org/10.4103/2384-5589.153391

10. Bukiran, A., Erdur, B., Ozen, M., \& Bozkurt, A. I. (2014). Retention of nurses' knowledge after basic life support and advanced cardiac life support training at immediate, 6-month, and 12-month post-training intervals: A longitudinal study of nurses in Turkey. Journal of Emergency Nursing, 40(2), $146-152$. https://doi.org/10.1016/j.jen.2012.08.011

11. Saiboon, I. M., Qamruddin, R. M., Jaafar, J. M., Bakar, A. A., Hamzah, F. A., \& Robertson, C. E. (2016). Effectiveness of teaching automated external defibrillators use using a traditional classroom instruction versus self-instruction video in non-critical care nurses. Saudi Medical Journal, 37(4), 429435. https://doi.org/10.15537/smj.2016.4.14833

12. Al-Kareem, M. A. A.-J. B. A. (2014). Assessment of nurses knowledge and skills in three districts hospital Bostwana.

13. Rajeswaran, L., Cox, M., Moeng, S., \& Tsima, B. M. (2018a). Assessment of nurses' cardiopulmonary resuscitation knowledge and skills within three district hospitals in Botswana. African Journal of Primary Health Care and Family Medicine, 10(1), 1-6. https://doi.org/10.4102/phcfm.v10i1.1633

14. Sopka, S., Biermann, H., Rossaint, R., Rex, S., Jäger, M., Skorning, M., Heussen, N., \& Beckers, S. K. (2013). Resuscitation training in small-group setting gender matters. Scandinavian Journal of Trauma, Resuscitation and Emergency Medicine, 21(1), 1-10. https://doi.org/10.1186/1757-7241-21-30

15. Kelkay, M. M., Kassa, H., Birhanu, Z., \& Amsalu, S. (2018). A cross sectional study on knowledge, practice and associated factors towards basic life support among nurses working in amhara region referral hospitals, northwest Ethiopia, 2016. Hospice and Palliative Medicine International Journal, 2(2), 123-130. https://doi.org/10.15406/hpmij.2018.02.00070

16. Boonmak, P., Boonmak, S., Srichaipanha, S., \& Poomsawat, S. (2004). Knowledge and skill after brief ACLS training. Journal of the Medical Association of Thailand, 87(11), 1311-1314.

17. Govender, K., Rangiah, C., Ross, A., \& Campbell, L. (2010). Retention of knowledge of and skills in cardiopulmonary resuscitation among healthcare providers after training. South African Family Practice, 52(5), 459-462. https://doi.org/10.1080/20786204.2010.10874025

18. Jensen, M. L., Lippert, F., Hesselfeldt, R., Rasmussen, M. B., Mogensen, S. S., Jensen, M. K., Frost, T., \& Ringsted, C. (2009). The significance of clinical experience on learning outcome from resuscitation training-A randomised controlled study. In Resuscitation (Vol. 80, Issue 2, pp. 238-243). https://doi.org/10.1016/j.resuscitation.2008.10.026

19. Smith, K. K., Gilcreast, D., \& Pierce, K. (2008). Evaluation of staff's retention of ACLS and BLS skills. Resuscitation, 78(1), 59-65. https://doi.org/10.1016/j.resuscitation.2008.02.007

20. Braslow, A., Brennan, R. T., Newman, M. M., Bircher, N. G., Batcheller, A. M., \& Kaye, W. (1997). CPR training without an instructor: Development and evaluation of a video self-instructional system for effective performance of cardiopulmonary resuscitation. Resuscitation, 34(3), 207-220. https://doi.org/10.1016/S0300-9572(97)01096-4

21. Bylow, H., Karlsson, T., Claesson, A., Lepp, M., Lindqvist, J., \& Herlitz, J. (2019). Self-learning training versus instructor-led training for basic life support: A cluster randomised trial. Resuscitation, 139(October 2018), 122-132. https://doi.org/10.1016/j.resuscitation.2019.03.026

22. Qui, D. M., Vargas, M. L., Fernández-lamas, N., \& Mejia, C. R. (2017). Revista Colombiana de Anestesiología Factors influencing the level of knowledge of. Revista Colombiana de Anestesiologia, 45(2), 114-121. https://doi.org/10.1016/j.rcae.2017.01.001

23. Soar, J., Mancini, M. E., Bhanji, F., Billi, J. E., Dennett, J., Finn, J., Huei-Ming Ma, M., Perkins, G. D., Rodgers, D. L., Hazinski, M. F., Jacobs, I., \& Morley, P. T. (2010). Part 12: Education, implementation, and teams: 2010 International consensus on cardiopulmonary resuscitation and emergency cardiovascular care science with treatment recommendations. Resuscitation, 81(1 SUPPL.1). https://doi.org/10.1016/j.resuscitation.2010.08.030

24. Mardegan, K. J., Schofield, M. J., \& Murphy, G. C. (2015). Comparison of an interactive CD-based and traditional instructor-led Basic Life Support skills training for nurses. Australian Critical Care, 28(3), 160-167. https://doi.org/10.1016/j.aucc.2014.06.001

25. Perkins, G. D., \& Mancini, M. E. (2009). Resuscitation training for healthcare workers. Resuscitation, 80(8), 841-842. https://doi.org/10.1016/j.resuscitation.2009.06.013

26. Aqel, A. A., \& Ahmad, M. M. (2014). High-Fidelity Simulation Effects on CPR Knowledge, Skills, Acquisition, and Retention in Nursing Students. Worldviews on Evidence-Based Nursing, 11(6), 394-400. https://doi.org/10.1111/wvn.12063

27. Chen, J., Yang, J., Hu, F., Yu, S. H., Yang, B. X., Liu, Q., \& Zhu, X. P. (2018). Standardised simulation-based emergency and intensive care nursing curriculum to improve nursing students' performance during simulated resuscitation: A quasi-experimental study. Intensive and Critical Care Nursing, 
46, 51-56. https://doi.org/10.1016/j.iccn.2018.02.003

28. Aliyari, shahla, Pishgooie, A. H., Abdi, A., Mazhari, M. S., \& Nazari, M. R. (2019). Comparing two teaching methods based on concept map and lecture on the level of learning in basic life support. Nurse Education in Practice, 38(April), 40-44. https://doi.org/10.1016/j.nepr.2019.05.008

29. Serwetnyk, T. M., Filmore, K., Vonbacho, S., Cole, R., Miterko, C., Smith, C., \& Smith, C. M. (2015). Comparison of Online and Traditional Basic Life Support Renewal Training Methods for Registered Professional Nurses. Journal for Nurses in Professional Development, 31(6), E1-E10. https://doi.org/10.1097/NND.0000000000000201

30. Kaye, W., Rallis, S. F., Mancini, M. E., Linhares, K. C., Angell, M. L., Donovan, D. S., Zajano, N. C., \& Finger, J. A. (1991). The problem of poor retention of cardiopulmonary resuscitation skills may lie with the instructor, not the learner or the curriculum. In Resuscitation (Vol. 21, Issue 1, pp. 67-87). https://doi.org/10.1016/0300-9572(91)90080-I

31. Castillo, J., Gomar, C., Rodriguez, E., Trapero, M., \& Gallart, A. (2019). Cost minimization 32 analysis for basic life support. Resuscitation, 134(May), 127-132. https://doi.org/10.1016/j.resuscitation.2018.11.008

32. Chung, C. H., Siu, A. Y. C., Po, L. L. K., Lam, C. Y., \& Wong, P. C. Y. (2010). Comparing the effectiveness of video self-instruction versus traditional classroom instruction targeted at cardiopulmonary resuscitation skills for laypersons: A prospective randomised controlled trial. Hong Kong Medical Journal, 16(3), 165-170.

33. Lumpur, K., Ruíz, A. A. B., Shahrakivahed, A., Masinaienezhad, N., Shahdadi, H., Arbabisarjou, A., Asadibidmeshki, E., Heydari, M., Kose, S., Akin, S., Mendi, O., Goktas, S., Roel, S., Bjørk, I. T., Bajracharya, S., Nagarkoti, L., Terzi, B., Polat, Ş., Düzkaya, D. S., ... Cheng, A. (2015). Comparison of an interactive CD-based and traditional instructor-led Basic Life Support skills training for nurses. Resuscitation, 31(4), E1-E10. https://doi.org/10.1097/NND.0000000000000201

34. Bajracharya, S., \& Nagarkoti, L. (2016). Knowledge Regarding Basic Life Support Among Nurses of a Tertiary Level Hospital of Nepal. Medical Journal of Shree Birendra Hospital, 15(1), 66-69. https://doi.org/10.3126/mjsbh.v15i1.15190

35. Vural, M., Koşar, M. F., Kerimoğlu, O., Kızkapan, F., Kahyaoğlu, S., Tuğrul, S., \& İşleyen, H. B. (2017). Cardiopulmonary resuscitation knowledge among nursing students:A questionnaire study. Anatolian Journal of Cardiology, 17(2), 140-145. https://doi.org/10.14744/AnatolJCardiol.2016.7156

36. Munezero, J. B. T., Atuhaire, C., Groves, S., \& Cumber, S. N. (2018). Assessment of nurses knowledge and skills following cardiopulmonary resuscitation training at Mbarara regional referral hospital, Uganda. Pan African Medical Journal, 30, 1-14. https://doi.org/10.11604/pamj.2018.30.108.15398

37. Saramma, P. P., Raj, L., Dash, P. K., \& Sarma, P. S. (2016). Assessment of long-term impact of formal certified cardiopulmonary resuscitation training program among nurses. Indian Journal of Critical Care Medicine, 20(4), 226-232. https://doi.org/10.4103/0972-5229.180043

38. Shahrakivahed, A., Masinaienezhad, N., Shahdadi, H., Arbabisarjou, A., Asadibidmeshki, E., \& Heydari, M. (2015). The Effect of CPR Workshop on the Nurses' Level of Knowledge and Skill. International Archives of Medicine, 1-10. https://doi.org/10.3823/1707

39. Partiprajak, S., \& Thongpo, P. (2016). Retention of basic life support knowledge, self-efficacy and chest compression performance in Thai undergraduate nursing students. Nurse Education in Practice, 16(1), 235-241. https://doi.org/10.1016/j.nepr.2015.08.012

40. Yılmaz, A., \& Simsek, E. (2019). Evaluation of cardiopulmonary resuscitation (CPR) practice of nurses at a tertiary hospital. Eastern Journal of Medicine, 24(2), 135-140. https://doi.org/10.5505/ejm.2019.48343

41. Hernández-Padilla, J. M., Suthers, F., Granero-Molina, J., \& Fernández-Sola, C. (2015). Effects of two retraining strategies on nursing students' acquisition and retention of BLS/AED skills: A cluster randomised trial. Resuscitation, 93, 27-34. https://doi.org/10.1016/j.resuscitation.2015.05.008

42. Toubasi, S., Alosta, M. R., Darawad, M. W., \& Demeh, W. (2015). Impact of simulation training on Jordanian nurses' performance of basic life support skills: A pilot study. Nurse Education Today, 35(9), 999-1003. https://doi.org/10.1016/j.nedt.2015.03.017

43. Terzi, B., Polat, Ş., \& Düzkaya, D. S. (2017). Evaluation of Basic Life Support Training Program Provided for Nurses in A University Hospital. Www.ljmrhs.Com International Journal of Medical Research \& Health Sciences, 6(6), 70-76.

44. Niles, D. E., Nishisaki, A., Sutton, R. M., Elci, O. U., Meaney, P. A., O’Connor, K. A., Leffelman, J., Kramer-Johansen, J., Berg, R. A., \& Nadkarni, V. (2017). Improved Retention of Chest Compression Psychomotor Skills with Brief "rolling Refresher" Training. Simulation in Healthcare, 12(4), 213-219. https://doi.org/10.1097/SIH.0000000000000228

45. Sullivan, N. J., Duval-Arnould, J., Twilley, M., Smith, S. P., Aksamit, D., Boone-Guercio, P., Jeffries, P. R., \& Hunt, E. A. (2015). Simulation exercise to improve retention of cardiopulmonary resuscitation priorities for in-hospital cardiac arrests: A randomized controlled trial. Resuscitation, 86, 6-13. https://doi.org/10.1016/j.resuscitation.2014.10.021

46. Anderson, R., Sebaldt, A., Lin, Y., \& Cheng, A. (2019). Optimal training frequency for acquisition and retention of high-quality CPR skills: A randomized trial. Resuscitation, 135(October 2018), 153-161. https://doi.org/10.1016/j.resuscitation.2018.10.033

47. Bhanji, F., Donoghue, A. J., Wolff, M. S., Flores, G. E., Halamek, L. P., Berman, J. M., Sinz, E. H., \& Cheng, A. (2015). Part 14: Education: 2015 American Heart Association guidelines update for cardiopulmonary resuscitation and emergency cardiovascular care. Circulation, 132(18), S561-S573. https://doi.org/10.1161/CIR.0000000000000268

48. Finn, J. C., Bhanji, F., Lockey, A., Monsieurs, K., Frengley, R., Iwami, T., Lang, E., Ma, M. H. M., Mancini, M. E., McNeil, M. A., Greif, R., Billi, J. E., Nadkarni, V. M., Bigham, B., Billi, J. E., Bray, J. E., Breckwoldt, J., Brooks, S. C., Cheng, A., ... Yeung, J. (2015). Part 8: Education, implementation, and teams. 2015 International Consensus on Cardiopulmonary Resuscitation and Emergency Cardiovascular Care Science with Treatment Recommendations. Resuscitation, 95, e203-e224. https://doi.org/10.1016/j.resuscitation.2015.07.046

49. Ackermann, A. D. (2009). Investigation of Learning Outcomes for the Acquisition and Retention of CPR Knowledge and Skills Learned with the Use of High-Fidelity Simulation. Clinical Simulation in Nursing, 5(6), 2019. https://doi.org/10.1016/j.ecns.2009.05.002 
50. Tawalbeh, L. I., \& Ahmad, M. M. (2013). Personal resource questionnaire: A systematic review. Journal of Nursing Research, 21(3), $170-177$. https://doi.org/10.1097/01.jnr.0000432049.31921.ab

51. Almeida, A. O. de, Araújo, I. E. M., Dalri, M. C. B., \& Araujo, S. (2011). Theoretical knowledge of nurses working in non-hospital urgent and emergency care units concerning cardiopulmonary arrest and resuscitation. Revista Latino-Americana de Enfermagem, 19(2), $261-268$. https://doi.org/10.1590/s0104-11692011000200006

52. Madden, C. (2006). Undergraduate nursing students' acquisition and retention of CPR knowledge and skills. Nurse Education Today, $26(3), 218-227$. https://doi.org/10.1016/j.nedt.2005.10.003

53. Gates; M. G. J. E. H. (2012). Enhancing Nursing Knowledge Using High-Fedelity Simulation J Nurs Educ. 2012 Jan;51(1):9-15. doi: 10.3928/0148483420111116-01.

54. González A.M., Ballesteros M.A., Merino F., Abajas R., González S., D. M. . (2013). What can bring high-fidelity simulation training in basic life support. 1800.

55. Ouseph B, S, M., L, T., \& A, A.-H. (2015). Nurses' Resuscitation Performance: Study on the Effectiveness of Training and Support at a Teaching Hospital in KSA. International Journal of Cardiovascular and Cerebrovascular Disease, 3(4), 21-27. https://doi.org/10.13189/ijccd.2015.030401

56. Bakhsha, F. (2010). Assessing the need and effect of updating the knowledge about cardio-pulmonary resuscitation in experts. Journal of Clinical and Diagnostic Research, 4(3), 2512-2514.

57. Elazazay, H. M., Abdelazez, A. L., \& Elsaie, O. A. (2012). Effect of cardiopulmonary resuscitation training program on nurses knowledge and practice. Life Science Journal,

58. L. Barimnejad PhD Student [1] , M. Rasouli MSc [2] , V. Barimnejad PhD [3], S. S. Ms. [4]. (2005). Frequency of Some of the Factors Affecting Adults Cardio -Pulmonary Resuscitation Outcome in Emam Khomeini Hospital.

59. Dong, R., Yang, X., Xing, B., Zou, Z., Zheng, Z., Xie, X., Zhu, J., Chen, L., \& Zhou, H. (2015). Use of concept maps to promote electrocardiogram diagnosis learning in undergraduate medical students. International Journal of Clinical and Experimental Medicine, 8(5), 7794-7801.

60. Cutrer, W. B., Castro, D., Roy, K. M., \& Turner, T. L. (2011). Use of an expert concept map as an advance organizer to improve understanding of respiratory failure. Medical Teacher, 33(12), 1018-1026. https://doi.org/10.3109/0142159X.2010.531159

61. Moser, D. K., \& Coleman, S. (1992). Recommendations for improving cardiopulmonary resuscitation skills retention. In Heart and Lung: Journal of Critical Care (Vol. 21, Issue 4, pp. 372-380).

62. Lewis FH, CC, K., \& MP, M. (1993). Revisiting CPR knowledge and skills among registered nurses. In Journal of Continuing Education in Nursing (Vol. 24, Issue 4, pp. 174-179). http://search.ebscohost.com/login.aspx?direct=true\&db=ccm\&AN=107474893\&amp\%0Alang=es\&site=ehost-live\&scope=site

63. Cooper, and L. (1997). A review of educational issues in resuscitation training. In Journal of Clinical Nursing (Vol. 6, Issue 1, pp. 5-10). https://doi.org/10.1111/j.1365-2702.1997.tb00283.x

64. Moule P and Knight C. (1997). Emergency, cardiac arrest! Can we teach the skills? in Nurse Educ Today 1997 Apr;17(2):99-105. doi: 10.1016/s02606917(97)80025-1.

65. Einspruch, E. L., Lynch, B., Aufderheide, T. P., \& Becker, L. (2007). Retention of CPR skills learned in a traditional AHA Heartsaver course versus 30-min video self-training: A controlled randomized study[. 476-486. https://doi.org/10.1016/j.resuscitation.2007.01.030

66. Young, R., \& King, L. (2000). An evaluation of knowledge and skill retention following an in-house advanced life support course. In Nursing in critical care (Vol. 5, Issue 1, pp. 7-14). http://www.ncbi.nlm.nih.gov/pubmed/11111632

67. Hamilton, R. (2005). Nurses' knowledge and skill retention following cardiopulmonary resuscitation training: A review of the literature. Journal of Advanced Nursing, 51(3), 288-297. https://doi.org/10.1111/j.1365-2648.2005.03491.x

68. Meaney, P. A., Sutton, R. M., Tsima, B., Steenhoff, A. P., Shilkofski, N., Boulet, J. R., Davis, A., Kestler, A. M., Church, K. K., Niles, D. E., Irving, S. Y., Mazhani, L., \& Nadkarni, V. M. (2012). Training hospital providers in basic CPR skills in Botswana: Acquisition, retention and impact of novel training techniques. Resuscitation, 83(12), 1484-1490. https://doi.org/10.1016/j.resuscitation.2012.04.014

69. Todd, K. H., Braslow, A., Brennan, R. T., Lowery, D. W., Cox, R. J., Lipscomb, L. E., \& Kellermann, A. L. (1998). Randomized, controlled trial of video selfinstruction versus traditional CPR training. Annals of Emergency Medicine, 31(3), 364-369. https://doi.org/10.1016/S0196-0644(98)70348-8

70. Huang, Y., Chen, H., Yeh, M., \& Chung, Y. (2012). International Journal of Nursing Studies Case studies combined with or without concept maps improve critical thinking in hospital-based nurses: A randomized-controlled trial. International Journal of Nursing Studies, 49(6),

71. Elen J, Clarebout G, Léonard R, Lowyck J. Student-centred and teacher-centred learning environments: what students think. Teach High Educ 2007;12:105-17.9(4), 3494-3503.

72. Hopstock LA. Motivation and adult learning: a survey among hospital personnel attending a CPR course. Resuscitation 2008;76:425-30.29

\section{Figures}




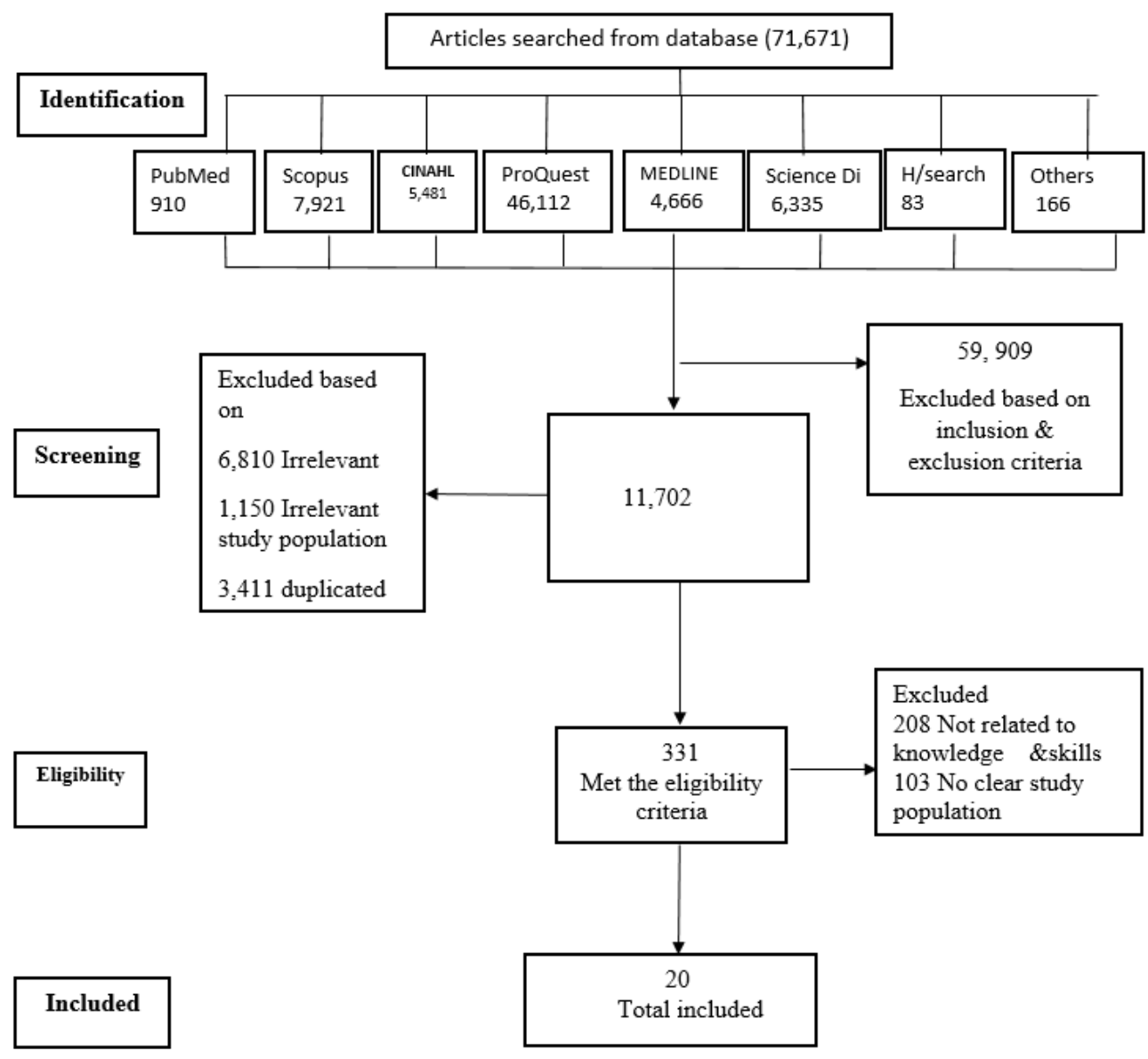

Figure 1

Flowchart of the review process.

\section{Supplementary Files}

This is a list of supplementary files associated with this preprint. Click to download.

- Additionalfile1.docx

- Additionalfile2.docx

- Additionalfile3.docx

- Additionalfile4.docx 